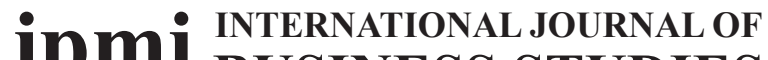 BUSINESS STUDIES
}

ISSN: 2580-0132

Vol. 1 | No. 1 (June 2017)

\section{Measuring Financial Performance of PT. Pos Indonesia During the E-commerce Booming}

\author{
Sasotya Pratama ${ }^{1 *}$ \\ ${ }^{1}$ Sekolah Tinggi Manajemen Ipmi, Jakarta 12750, Indonesia
}

\begin{abstract}
A B S T RA C T
Advancement of telecommunications technology and Internet protocol has encouraged the development of services through electronic commerce (e-commerce). The growth of over $35 \%$ per year has been achieved by the industry since 2013 in Indonesia. More than ten companies operate in the industry. In line with the development of e-commerce services, also developed supporting industries such as logistics, to deliver products purchased over the Internet. There are about three big private companies in the courier industries, and the only state-owned enterprises (SOEs) in the courier industry is PT. Pos Indonesia (PTPI). The purpose of this study is to measure and evaluate the financial health condition of PTPI for periods of 20092015 by investigating its financial ratios included return on equity, return on investment, cash ratio, current ratio, collection period, inventory turnover, total asset turnover, and total equity to the total asset. The result shows achieved financial health condition of PTPI and can be used to advise further improvements.
\end{abstract}

ART ICLE INFO

Financial Performance,

E-commerce,

State-owned Enterprises,

PT. Pos Indonesia

${ }^{*}$ Corresponding author Email:

sasotya.pratama@ipmi.ac.id

Copyright $(\odot$ 2017Authors. This is an open access article distributed under the Creative Commons Attribution License, which permits unrestricted use, distribution, and reproduction in any medium, provided the original work is properly cited.

\section{INTRODUCTION}

The global e-commerce industry is currently growing very fast due to the development of telecommunications and information technologies. The industry had been initiated by industry players since the beginning of this millennium. In Indonesia, some e-commerce platforms have been established since 1999, such as Bhinneka and Kaskus. However, the e-commerce industry in Indonesia has increased sharply after 2010 with the increasing number of e-commerce platform establishment such as Tokopedia in 2009, Blibli in 2011, Bukalapak in 2012, Lazada in 2012, Traveloka in 2012, Berybenka in 2013, OLX in 2014, Elevenia in 2014, and MatahariMall in 2015 (Mars Indonesia, 2016). Table 1 shows the development of product sales in the industry in five countries in Asia for the period of 2013 to 2016. 
Table 1. The Growth of Product Sales in the E-Commerce Industry

\begin{tabular}{|c|c|c|c|c|}
\hline $\begin{array}{l}\text { Estimated } \\
\text { B2C E-commerce } \\
\text { Sales 2013-2016 } \\
\text { (in billion) }\end{array}$ & 2013 & 2014 & 2015 & 2016 \\
\hline China & $\$ 181.62$ & $\$ 274.57$ & $\$ 358.59$ & $\$ 439.72$ \\
\hline Japan & $\$ 118.59$ & $\$ 127.06$ & $\$ 135.54$ & $\$ 143.13$ \\
\hline Korea & $\$ 18.52$ & $\$ 20.24$ & $\$ 21.92$ & $\$ 23.71$ \\
\hline India & $\$ 16.32$ & $\$ 20.74$ & $\$ 25.65$ & $\$ 30.31$ \\
\hline Indonesia & $\$ 1.79$ & $\$ 2.60$ & $\$ 3.56$ & $\$ 4.89$ \\
\hline
\end{tabular}

Source: PT. Mars Indonesia (2017)

In Indonesia, the sales revenues generated through e-commerce has grown by $45 \%$ from 2013 to $2014 ; 37 \%$ from 2014 to 2015 ; and 37\% from 2015 to 2016 (E-commerce Study for 2016, PT Mars Indonesia). The Business to Consumer (B2C) type of trading is growing faster than the Business to Business (B2B) and the Business to Government (B2G) types. Singapore Post Limited (2016) has projected Indonesia's GDP to grow at an average of $5.2 \%$ in 2020 , with its e-commerce market growth of 31.1\% CAGR to reach US\$3,800 million by 2019 . Online sales jumped from $0.4 \%$ of Indonesia retail revenue in 2014 to an estimated $4.4 \%$ by 2019 . This shows significant growth and increasing level of ecommerce penetration.

The development of e-commerce industry has fueled the development of supporting industries, among others, courier and logistics industry. Delivery of products purchased over the Internet has grown substantially. Some national logistics companies that have been operating in Indonesia are PT. Tiki Jalur Nugraha Ekakurir (JNE), PT. Pos Indonesia, PT. TIKI, PT. NEX Logistic. One private company engaged in logistics, the JNE, stated that $60 \%$ of its revenue comes from e-commerce service delivery (Bisnis.com, 2016).

However, the logistic industry has faced many problems. According to Syarifudin (2017), the main problems are poor infrastructure. Goods sent to remote areas will be more expensive compared with goods located in the city center. The other problems are the issue of regulation that needs to be upheld and less qualified human resources. In 2003, PT Pos Indonesia suffered losses because 71 percent of its 3,398 branches in Indonesia are not functioning. It losses reached Rp 367 billion due to PSO funds (Public Service Obligation) submitted to the Government is still below the target. Based on the figure 1, this company has suffered from losses until 2008, then it gained profit around 5.33\% in 2012.

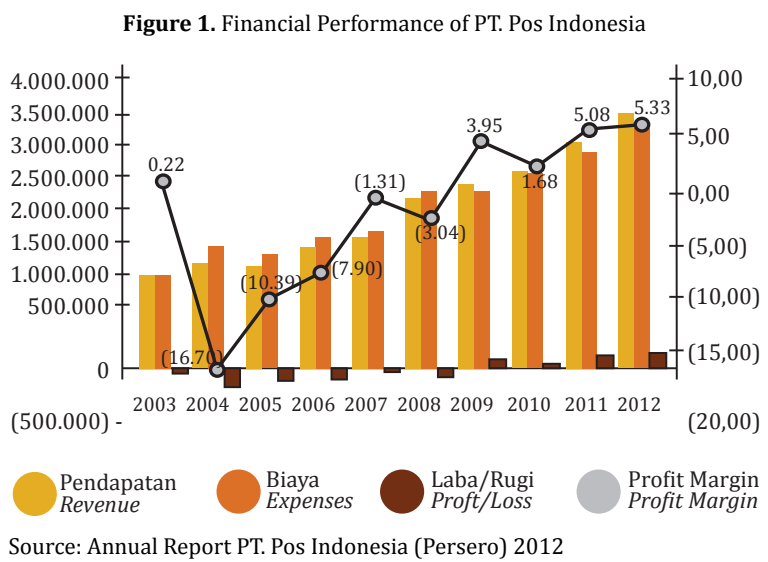

The purpose of this study is to measure and evaluate the financial health condition of PT. Pos Indonesia for the periods of 2009-2015 by investigating its financial ratios included return on equity, return on investment, cash ratio, current ratio, collection period, inventory turnover, total asset turnover, and total equity to the total asset. The study would be beneficial to teachers and students as reference to understand the financial performance in logistic industry. The present study will extend existing knowledge about financial performance. The finding of this study also will help practitioners to create a better financial strategy. This research is organized into five parts, namely part 1 present the introduction, part 2 overview the literature, part 3 discuss the research methodology, part 4 analyze the finding, and part 5 conclude the research and give recommendation.

\section{LITERATURE REVIEW}

\section{The Development of PT. Pos Indonesia}

PT Pos Indonesia (PTPI) is a State-Owned Enterprises (SOEs) which is engaged in courier, logistics, and financial transactions. Although rooted in a long history, ie since 1906, the name of PT Pos Indonesia (PTPI) was just used in 1995. In 1906, the forerunner of PTPI was established with the official name of the PTT (Posts Telegraaf en Telefoon Diensts) which later changed to Djawatan 
PTT (Postal Telegraph and Telephone) in 1945. In 1961, the Department of PTT changed its status to the State Enterprise of Posts and Telecommunications (PN Postel) and became PN Pos \& Giro in 1965, as well as being Perum Pos and Giro in 1978.

The rapid development of telecommunications and Internet technologies, the development of lifestyle, as well as the trend of liberalization of the postal service businesses make business PTPI has shifted significantly. The decline in operating performance of PTPI was seen in the year 20002007, which is also experienced by many other postal companies in the world. Post and package business declined drastically because of their substitutes in the form of a short message service via mobile phone and e-mail via the Internet which replaced the role of individual postal mail. Likewise, shipments competition with private courier companies made PTPI market share declined.

PTPI answered these conditions by doing a business transformation. Management has determined the wake of the company in 2009 by drafting a new vision and mission which is expected to be more adaptive to the dynamic business environment. Through various internal transformation program, revenues of PTPI in 2014 has reached more than four trillion rupiahs or increased almost three-fold from 2006-2007. For the next three years, all leaders of PTPI are targeting revenue growth of the company tripled from 2014 , be 12 trillion rupiahs.

\section{Previous Research on Financial Performance}

A financial ratio is considered as one of good evaluation methods to measure company performances (Megaladevi, 2015). This method is usually employed by companies to compare their performances against competitors. A lot of empirical studies on financial ratio on different industries can be found and studied (Tarawneh, 2006; Halkos and Salamouris, 2004). On the banking industry, the financial ratio analysis has been applied to evaluate, examine, and rank based on their performance (Tarawneh, 2006). A study in Oman Commercial Bank showed that the financial performance had a relationship with asset management, size, and operational efficiency. However, only limited resources which evaluate the financial performance of courier and or logistic companies in Indonesia are found.

The Decree of Ministry of State-Owned Enterprises The Decree of Ministry SOEs No. KEP100/MBU/2002 on financial health assessment of SOEs emphasizes that the growth of businesses must be supported by good infrastructures and reliable evaluation systems. The Decree, as a convenient evaluation system, has also been used to measure efficiency and competitiveness of SOEs. This financial evaluation applies to all SOEs in the financial, infrastructure, and noninfrastructure industries. Three aspects are evaluated by this Decree such as financial, operational, and administrations. For financial aspects, the total weight for infrastructure industries is 50 while for the non-infrastructure ones is 70. Eight indicators are used to measure the financial health included return on investment (ROI), return on equity (ROE), cash ratio, current ratio (CR), collection period (CP), inventory turnover (ITO), total assets turnover (TATO), and total equity to the total assets (TETA). PTPI is

Table 2. Key Performances of PT. Pos Indonesia

\begin{tabular}{|l|c|c|c|c|c|}
\hline Indicators & 2011 & 2012 & 2013 & 2014 & 2015 \\
\hline Revenues (in Millions IDR) & $3,006,012$ & $3,335,875$ & $4,174,896$ & $4,360,550$ & $4,568,571$ \\
\hline Revenues Growth & $17 \%$ & $11 \%$ & $25 \%$ & $4 \%$ & $5 \%$ \\
\hline Operating profit & 151,234 & 205,644 & 306,015 & 265,493 & 40,882 \\
\hline Employees & N/A & 20.170 & 19,502 & 19,392 & 18,842 \\
\hline Post Offices & N/A & 3,711 & 4,076 & 3,700 & 4,561 \\
\hline Service Point & 22,045 & 24,000 & 24,674 & 28,899 & 38,116 \\
\hline
\end{tabular}

Source: Annual Report PT. Pos Indonesia From 2011 to 2015 
listed in non-infrastructure industries under stateowned enterprises which the list of assessments score shows on table 2.

Table 2. List of Assessment Score

\begin{tabular}{|l|c|}
\hline INDICATORS & WEIGHT SCORE \\
\hline ROE & 20 \\
\hline ROI & 15 \\
\hline Cash Ratio & 5 \\
\hline Current Ratio & 5 \\
\hline Collection Period & 5 \\
\hline Inventory Turnover & 5 \\
\hline Total Asset Turnover & 5 \\
\hline Total Equity to Total Asset & 10 \\
\hline Total weight score & 70 \\
\hline
\end{tabular}

Source: The decree of Ministry of SEOs No. Kep 100/MBU/2002

\section{The Variable and Weight Score}

\section{a. Profitability Performance}

The profitability is the most common measure for company's financial performance. The equation for profitability measurement can be expressed as Return on Equity $(R O E)=\left(\frac{\text { Net Income }}{\text { Shareholders'Equity }}\right) \times 100 \%$. Return on equity is an important ratio for investors to consider its profits. According to Anthony (2011), ROE measures how efficiently a company can use the money from shareholders to generate profits and grow the company. Table 3 shows the assessment score of ROE.

Table 3. List of ROE Assessment Score

\begin{tabular}{|c|c|}
\hline ROE $(\%)$ & WEIGHT SCORE \\
\hline $15<\mathrm{ROE}$ & 20 \\
\hline $13<\mathrm{ROE}<=15$ & 18 \\
\hline $11<\mathrm{ROE}<=13$ & 16 \\
\hline $9,0<\mathrm{ROE}<=11$ & 14 \\
\hline $7,9<\mathrm{ROE}<=9$ & 12 \\
\hline $6,6<\mathrm{ROE}<=7,9$ & 10 \\
\hline $53<\mathrm{ROE}<=6,6$ & 8,5 \\
\hline $40<\mathrm{ROE}<=5,3$ & 7 \\
\hline $2,5<\mathrm{ROE}<=4$ & 5,5 \\
\hline $1,0<\mathrm{ROE}<=2,5$ & 4 \\
\hline $0<\mathrm{ROE}<=1$ & 2 \\
\hline $\mathrm{ROE}<=0$ & 0 \\
\hline
\end{tabular}

Source: The decree of Ministry of SEOs No. Kep 100/MBU/2002

Return on investment is a profitability ratio that calculates the profits of an investment as a percentage of the original cost. The equation of ROI can be expressed as Return on Investment (ROI)= $\left(\begin{array}{c}\text { EBIT+Depreciation } \\ \text { Capital Employed }\end{array}\right) \times 100 \%$. and table 4 shows the assessment score of ROI.

Table 4. List of ROI Assessment Score

\begin{tabular}{|c|c|}
\hline ROI $(\%)$ & WEIGHT SCORE \\
\hline $18<\mathrm{ROE}$ & 15 \\
\hline $15<\mathrm{ROI}<=18$ & 13,5 \\
\hline $13<\mathrm{ROI}<=15$ & 12 \\
\hline $12<\mathrm{ROI}<=13$ & 10,5 \\
\hline $10,5<\mathrm{ROI}<=12$ & 9 \\
\hline $9<\mathrm{ROI}<=10,5$ & 7,5 \\
\hline $7<\mathrm{ROI}<=9$ & 6 \\
\hline $5<\mathrm{ROI}<=7$ & 5 \\
\hline $3<\mathrm{ROI}<=5$ & 4 \\
\hline $1<\mathrm{ROI}<=3$ & 3 \\
\hline $0<\mathrm{ROI}<=1$ & 2 \\
\hline $\mathrm{ROI}<=0$ & 1 \\
\hline
\end{tabular}

Source: The decree of Ministry of SEOs No. Kep 100/MBU/2002

\section{b. Liquidity Performance}

The equation of liquidity performance can be expressed as Cash Ratio $=\left(\frac{\text { Cash+Cash Equivalents }}{\text { Current Liabilities }}\right) \times 100 \%$. It measures the company ability to pay its shortterm debt. If the company has cash ratio equal to one, it indicates that company has the same amount of cash and its debt. If the value of cash ratio is more than 1 , it indicates that company has more cash to pay its debt. However, if the value is less than 1 , it indicates that company has less cash to pay its debt. Table 5 shows the assessment score for cash ratio.

Table 5. List of Cash Ratio Assessment Score

\begin{tabular}{|c|c|}
\hline Cash Ratio $=\mathbf{x}(\mathbf{\%})$ & Score \\
\hline $\mathbf{x}>=\mathbf{3 5}$ & 5 \\
\hline $\mathbf{2 5}<=\mathbf{x}<\mathbf{3 5}$ & 4 \\
\hline $\mathbf{1 5}<=\mathbf{x}<\mathbf{2 5}$ & 3 \\
\hline $\mathbf{2 0}<=\mathbf{x}<\mathbf{1 5}$ & 2 \\
\hline $\mathbf{5}<=\mathbf{x}<\mathbf{1 0}$ & 1 \\
\hline $\mathbf{0}<=\mathbf{x}<\mathbf{5}$ & 0 \\
\hline
\end{tabular}

Source: The decree of Ministry of SEO No. Kep 100/MBU/2002

In addition, the liquidity performance expressed in the formula as Current Ratio $=\left(\frac{\text { Current Asset }}{\text { CurrentLiabilities }}\right) \times 100 \%$. It measures the company ability to repay its current liability with current asset. If the company has a current ratio below 1 , it indicates that company has a problem with its short-term debt. If the company has a too high current ratio, it indicates that company has a problem in managing their current asset. Table 6 shows the current ratio assessment 
score.

Table 6. List of Current Ratio Assessment Score

\begin{tabular}{|c|c|}
\hline Current Ratio $=\mathbf{x}$ (\%) & Score \\
\hline $125<=\mathrm{x}$ & 5 \\
\hline $110<=\mathrm{x}<125$ & 4 \\
\hline $100<=\mathrm{x}<110$ & 3 \\
\hline $95<=\mathrm{x}<100$ & 2 \\
\hline $90<=\mathrm{x}<95$ & 1 \\
\hline $\mathrm{x}<90$ & 0 \\
\hline
\end{tabular}

Source: The decree of Ministry of SEO No. Kep 100/MBU/2002

Furthermore, the liquidity performance also can be

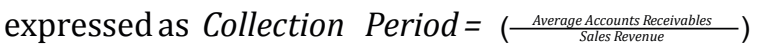
$\mathrm{x} 365$ days. This ratio is an important indicator for the company to monitor their cash flow and the company ability to pay its debt in due date. Table 7 shows the assessment score for collection period.

Table 7. List of Collection Periods Assessment Score

\begin{tabular}{|c|c|c|}
\hline $\begin{array}{l}\text { Collection Periods } \\
=\mathbf{x} \text { (days) }\end{array}$ & Adjustment (days) & Score \\
\hline $\mathrm{x}<==60$ & $30<\mathrm{x}$ & 5 \\
\hline $60<\mathrm{x}<=90$ & $30<\mathrm{x}<=35$ & 4,5 \\
\hline $90<\mathrm{x}<=120$ & $25<\mathrm{x}<=30$ & 4 \\
\hline $120<\mathrm{x}<=150$ & $20<\mathrm{x}<=25$ & 3,5 \\
\hline $150<\mathrm{x}<=180$ & $15<\mathrm{x}<=20$ & 3 \\
\hline $180<\mathrm{x}<=210$ & $10<\mathrm{x}<=15$ & 2,4 \\
\hline $210<\mathrm{x}<=240$ & $6<\mathrm{x}<=10$ & 1,8 \\
\hline $240<\mathrm{x}<=270$ & $3<\mathrm{x}<=6$ & 1,2 \\
\hline $270<\mathrm{x}<=300$ & $1<\mathrm{x}<=3$ & 0,6 \\
\hline $300<\mathrm{x}$ & $0<\mathrm{x}<=1$ & 0 \\
\hline
\end{tabular}

Source: The decree of Ministry of SEOs No. Kep 100/MBU/2002

\section{c. Activity Ratio}

This ratio measures how many time the inventory are being sold over a period. The activity ratio can be expressed in an equation as Inventory Turnover $=$

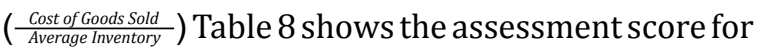
inventory turnover.
Table 8. List of Collection Periods Assessment Score

\begin{tabular}{|c|c|c|}
\hline $\begin{array}{c}\text { Collection Periods } \\
=\mathbf{x} \text { (days) }\end{array}$ & Adjustment (days) & Score \\
\hline $\mathrm{x}<=60$ & $30<\mathrm{x}$ & 5 \\
\hline $60<\mathrm{x}<=90$ & $30<\mathrm{x}<=35$ & 4,5 \\
\hline $90<\mathrm{x}<=120$ & $25<\mathrm{x}<=30$ & 4 \\
\hline $120<\mathrm{x}<=150$ & $20<\mathrm{x}<=25$ & 3,5 \\
\hline $150<\mathrm{x}<=180$ & $15<\mathrm{x}<=20$ & 3 \\
\hline $180<\mathrm{x}<=210$ & $10<\mathrm{x}<=15$ & 2,4 \\
\hline $210<\mathrm{x}<=240$ & $6<\mathrm{x}<=10$ & 1,8 \\
\hline $240<\mathrm{x}<=270$ & $3<\mathrm{x}<=6$ & 1,2 \\
\hline $270<\mathrm{x}<=300$ & $1<\mathrm{x}<=3$ & 0,6 \\
\hline $300<\mathrm{x}$ & $0<\mathrm{x}<=1$ & 0 \\
\hline \multicolumn{2}{|c|}{} & \multicolumn{2}{|c|}{} \\
\hline
\end{tabular}

Source: The decree of Ministry of SEOs No. Kep 100/MBU/2002 In addition, this ratio measures the efficiency of company ability to use its asset to generate sales. It can be expressed in the formula as Total Asset Turnover $=\left(\frac{\text { Revenue }}{\text { Capital Imployed }}\right) \times 100 \%$. Table 9 shows the total asset turnover assessment score.

Table 9. List of Total Asset Turnover Assessment Score

\begin{tabular}{|c|c|c|}
\hline TATO + X (\%) & Adjustment $=\mathbf{~ \% ) ~}$ & Score \\
\hline $120<X$ & $20<x$ & 5 \\
\hline $105<x<=120$ & $15<x<=20$ & 4,5 \\
\hline $90<x<=105$ & $10<x<=15$ & 4 \\
\hline $75<x<=90$ & $5<x<=10$ & 3,5 \\
\hline $60<x<=75$ & $0<x<=5$ & 3 \\
\hline $40<x<=60$ & $\mathrm{X}<=0$ & 2,5 \\
\hline $20<x<=40$ & $\mathrm{X}<0$ & 2 \\
\hline $\mathrm{X}<=20$ & $\mathrm{X}<0$ & 1,5 \\
\hline
\end{tabular}

Source: The decree of Ministry of SEO No. Kep-100/MBU/2002

\section{d. Solvency Ratio}

This ratio is similar to debt to equity ratio. If the company has less value, it indicates that company funding its asset inefficiently. In the other words, the company has very low net value for the investor. This ratio can be expressed in an equation as Total Equity to Total Asset $=\left(\frac{\text { Total Equity }}{\text { Total lasset }}\right) \times 100 \%$. Table 10 shows the solvency assessment score. 
Table 10. List of Solvency Assessment Score

\begin{tabular}{|c|c|}
\hline $\begin{array}{c}\text { Total Equity to } \\
\text { Total Asset }(\%)=\mathbf{~}\end{array}$ & Score \\
\hline $\mathbf{x}<\mathbf{0}$ & 0 \\
\hline $\mathbf{0}<=\mathbf{x}<\mathbf{1 0}$ & 4 \\
\hline $\mathbf{1 0}<=\mathbf{x}<\mathbf{2 0}$ & 6 \\
\hline $\mathbf{2 0}<=\mathbf{x}<\mathbf{3 0}$ & 7,25 \\
\hline $\mathbf{3 0}<=\mathbf{x}<\mathbf{4 0}$ & 10 \\
\hline $\mathbf{4 0}<=\mathbf{x}<\mathbf{5 0}$ & 9 \\
\hline $\mathbf{5 0}<=\mathbf{x}<\mathbf{6 0}$ & 8,5 \\
\hline $\mathbf{6 0}<=\mathbf{x}<\mathbf{7 0}$ & 8 \\
\hline $\mathbf{7 0}<=\mathbf{x}<\mathbf{8 0}$ & 7,5 \\
\hline $\mathbf{8 0}<=\mathbf{x}<\mathbf{9 0}$ & 7 \\
\hline $\mathbf{9 0}<=\mathbf{x}<\mathbf{1 0 0}$ & 6,5 \\
\hline &
\end{tabular}

Source: The decree of Ministry of SEOs No. Kep-100/MBU/2002

\section{METHODOLOGY}

PTPI is a State-Owned Enterprises based on the decree of Ministry of State Owned Enterprises No. KEP-100/MBU/2002. PTPI is categorized as a noninfrastructure company. Therefore, the descriptive financial ratio was used to describe, measure, analyze, and then evaluate the financial health condition of PTPI. The data were collected from its audited Annual Report between 2009 and 2015.

The level of financial assessment was divided into very healthy (the highest level of financial literacy), healthy (the middle level of financial literacy), and unhealthy (the lowest level of financial literacy). In the highest category, there are three levels of very healthy specification: AAA (total score achieved is more than 95 points), AA (total score achieved is more than 80 and less than 95), and A (total score achieved is more than 65 and less than 80 ). In the middle category, there are also three levels of very healthy specification: BBB (total score achieved is more than 50 and less than 65), BB (total score achieved is more than 40 and less than 50 ), and $B$ (total score achieved is more than 30 and less than 40). In the lowest category, as well, there are three levels of very healthy specification: CCC (total score achieved is more than 20 and less than 30), CC (total score achieved is more than 10 and less than 20), and C (total score achieved is less than 10).

The Financial Ratio Analysis method for this study is considered by the researcher due to the limited literature review on courier industry in Indonesia. In addition to that, financial ratios can be used to identify a company's specific strengths and weaknesses as well as providing detailed information about company profitability, liquidity, activity, and solvency (Hempel et al, 1994). The accounting data in financial statements is the only detailed information available on the corporate's overall activities despites its weaknesses because it is subject to it has backward looking characteristic (Sinkey, 2002). Furthermore, they are the only source of information for evaluating management's potential to generate satisfactory returns in the future (Mabwe Kumbirai, Robert Webb, 2010).

\section{RESULT AND DISCUSSION Profitability Performance}

The profitability performances of PT. Pos Indonesia were very poor during the period of $2009-2015$. Based on figure 1, The percentage of ROI was fluctuated from $3.70 \%$ in 2009 , it decreased to $2.50 \%$ in 2010 , then it increased from $6.08 \%$ in 2011 to $6.47 \%$ in 2012 and $7.17 \%$ in 2013. It decreased from $6.36 \%$ in 2014 to $3.19 \%$ in 2015 . The percentage of ROE was decreased from $25.73 \%$ in 2009 to $2.44 \%$ in 2015.

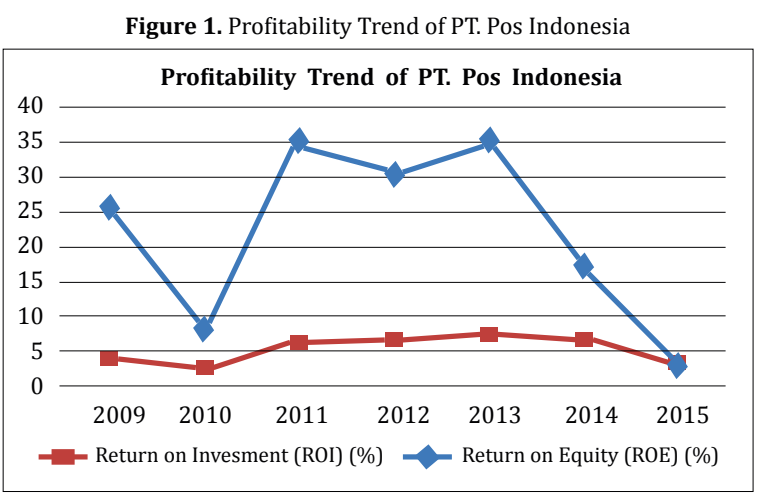

\section{Liquidity Performance}

Figure 2. shows the percentages of cash ratios and current ratios of PTPI from 2009 to 2015. Overall, there were significant increases in the percentage of cash ratio and current ratio in 2011, 2012 and 2013. But then the two ratios decreased in 2014 and 2015. The cash ratio percentages in 2009-2015 were 79.89\%; 80.26\%; 80.32\%; 86.93\%; 113.33\%; 79.16\%; and 78.01\% respectively. And current ratio percentages were $96.94 \%$; $96.18 \%$; $102.4 \% ; 106.68 \%$ : 109.21\%; $105.57 \%$ and 
$102.58 \%$ respectively. The highest and the lowest ratios were cash ratio. The current ratio is the general indicator to measure the liquidity of the company, and all the ratios are in close to $100 \%$. Every $\$ 1$ of short-term debt is backed up by $\$ 1$ of a current asset. The company can optimally manage its working capital within safe limits. So, it does not have short-term financial problems or the company is in a liquid condition.

Figure 2. Liquidity Trend of PT. Pos Indonesia

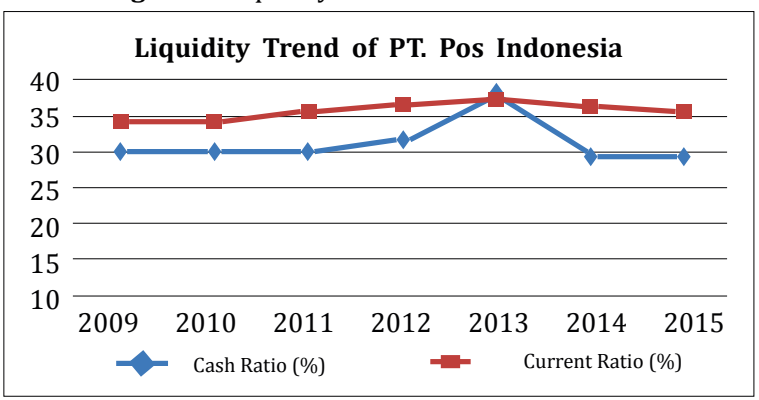

\section{Activity Performance}

Figure 3. gives information about the inventory turnover (ITO) and the percentages of total assets turnover (TATO) of PTPI between 2009 and 2015. Overall, there was a slight decrease in the number of those two parameters. In inventory turnover (ITO), number of days were $1 ; 1 ; 1 ; 0 ; 0.09 ; 2.00$ and 2.07 respectively in 2009-2015. The percentages of total assets turnover (TATO) during 7 years were: $23.7 \%$; $60.58 \% ; 73.26 ; 75.04 ; 75.80 ; 88.46$; and 88.99 respectively. It can be concluded that those two ratios were in good condition and the management of assets run efficiently.

The collection periods varied from the year 20092015 and it shows a declined trend. The collection periods from 2009-2015 are: 54, 50, 43, 28, 42.04, 33 , and 36.99 days. There was a decreased trend and it means that the collection periods were getting better after the year of 2009.

Figure 3. Activity Trend of PT. Pos Indonesia

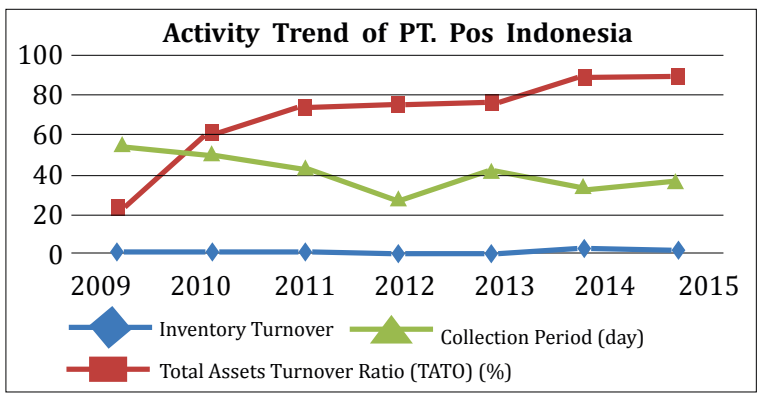

\section{Solvency Performance}

Figure 4. shows the percentage of the total of equity to total asset (TETA) ratio of PTPI between 2009 and 2015. Overall, there were fluctuated in the TETA ratios, 9.6\%; 9.68\%; 13.52\%; 16.71\%; 17.55\%; $20.85 \%$; and $17.43 \%$ respectively from 2009 to 2015. In the long term, the company rated insolvent because the average ratio of total equity to a total asset for the last 7 years was only $15.05 \%$, where the general standard was $50 \%$. It shows that the risks of the company were high unless the company can achieve high profit.

Figure 4. Solvency Trend of PT. Pos Indonesia

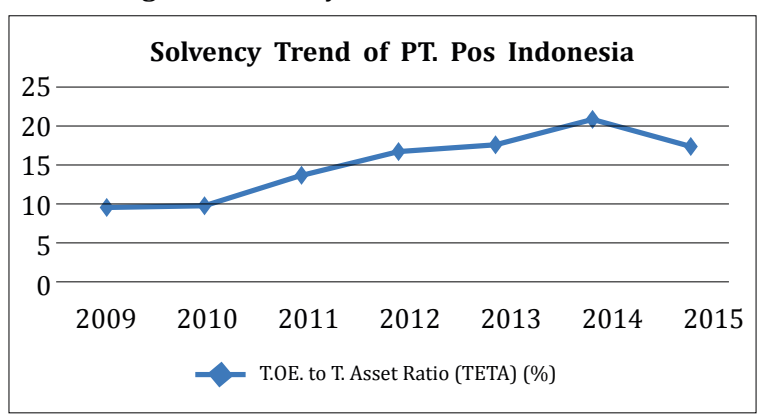

\section{Validation Testing}

To examine the level of financial assessment for PTPI, whether it is in a very healthy or healthy or unhealthy position from 2011-2015, the decree of Ministry of State Owned Enterprises No. KEP$100 / \mathrm{MBU} / 2002$ is employed to test the validation.

Table 11 shows the test results for PTPI during 2011 to 2015. Overall, there was a fluctuate decrease in the total score during 2011 to 2015 (52.00; 52.50; 53.50; 53.75; and 35.50). Next, the total score converted to the total weight with the calculation formula, which is total score/weight multiplied by 100 , and the result is shown in table VI.2. During the first four years, 2011 to 2014, the weighted scores were 70.00; 75.00; 76.43; 76.79 with the level of $\mathrm{A} ; \mathrm{A} ; \mathrm{A}$; and A respectively, and considered as very healthy financial condition. While for the last one year, 2015, the weighted score was 50.71; with levels of BBB (healthy). 
Table 11. Test Result for PT. Pos Indonesia

\begin{tabular}{|l|c|c|c|c|c|c|c|c|c|c|}
\hline \multirow{2}{*}{ INDICATORS } & \multicolumn{2}{|c|}{$\mathbf{2 0 1 5}$} & \multicolumn{2}{|c|}{$\mathbf{2 0 1 4}$} & \multicolumn{2}{|c|}{$\mathbf{2 0 1 3}$} & \multicolumn{2}{|c|}{$\mathbf{2 0 1 2}$} & \multicolumn{2}{|c|}{$\mathbf{2 0 1 1}$} \\
\cline { 2 - 12 } & RATIO & SCORE & RATIO & SCORE & RATIO & SCORE & RATIO & SCORE & RATIO & SCORE \\
\hline ROE & 2,44 & 4 & 17,32 & 20 & 35,52 & 20 & 30,48 & 20 & 35,28 & 20 \\
\hline ROI & 3.19 & 4 & 6,36 & 5 & 7,17 & 6 & 6,47 & 5 & 6,08 & 5 \\
\hline CASH RATIO & 78,01 & 5 & 79,16 & 5 & 113,33 & 5 & 86,93 & 3 & 102,40 & 3 \\
\hline CURRENT RATIO & 102,58 & 3 & 105,57 & 3 & 109,21 & 3 & 106,68 & 0 & 29,46 & 0 \\
\hline $\begin{array}{l}\text { COLLECTION } \\
\text { PERIOD }\end{array}$ & 36,99 & 5 & 33,0 & 5 & 42,04 & 5 & 28,0 & 5 & 43,0 & 5 \\
\hline $\begin{array}{l}\text { INVENTORY } \\
\text { TURNOVER }\end{array}$ & 2.07 & 5 & 2,0 & 5 & 0,09 & 5 & 0 & 5 & 1,0 & 5 \\
\hline $\begin{array}{l}\text { TATO } \\
\text { TOTAL EQUITY } \\
\text { TO TOTAL ASSET }\end{array}$ & 17,43 & 6 & 20,85 & 7,25 & 17,55 & 6 & 16,71 & 6 & 13,52 & 6 \\
\hline & TOTAL & 35,5 & Total & 53,75 & Total & 53,50 & Total & 52,50 & Total & 52,00 \\
\hline
\end{tabular}

Table 12. Summary Result for PT. Pos Indonesia

\begin{tabular}{|c|c|c|c|c|c|c|}
\hline Year & Total Score & Weight & $\begin{array}{c}\text { Total } \\
\text { Weight }\end{array}$ & Value & Level & Category \\
\hline 2015 & 35,50 & 70 & 50,71 & $50<\mathrm{TS}<=65$ & BBB & Healthy \\
\hline 2014 & 53,75 & 70 & 76,79 & $50<\mathrm{TS}<=80$ & A & Total Healthy \\
\hline 2013 & 53,50 & 70 & 76,43 & $50<\mathrm{TS}<=80$ & A & Total Healthy \\
\hline 2012 & 52,50 & 70 & 75,00 & $50<\mathrm{TS}<=80$ & A & Total Healthy \\
\hline 2011 & 52,00 & 70 & 70,00 & $50<\mathrm{TS}<=80$ & A & Total Healthy \\
\hline
\end{tabular}

\section{CONCLUSION AND RECOMMENDATION}

The result of analysis and calculation on PTPI's financial performance during 2011 until 2015 using financial ratio analysis method shows that PTPI reaches health level 'very healthy rank A' in 20112014. Even in 2015 PTPI only achieve 'healthy' with $B B B$ rating. Given that the 'very healthy' level has $\mathrm{AAA}, \mathrm{AA}$, and A ratings, with the highest rating being AAA, then achievement of an A rating can be considered as not a good enough taken into account the advancement of e-commerce industry in Indonesia. Meanwhile, the data of one of PTPI's main competitors in the courier service industry, JNE, shows that the main competitor has experienced a $30 \%$ continuous increase in revenue since 2013.

PTPI data obtained from the audited annual report 2009-2015 also shows that PTPI's operating profit declined drastically after 2013. Although the operating profit data is PTPI consolidated data with several subsidiaries, the decline in operating profit indicates a mismanagement of the company. This conclusion is reasonable because some subsidiaries of PTPI are also engaged in the supporting industries of e-commerce business.

Finally, this study has enriched the literature about financial performance in the real working world. In near future, it is suggested to conduct research involving many companies from the courier industry to get more generalizes results. Since the focus is on one industry, it is worth to explore it on a wider scale and find out whether different companies yield the same result. In addition to that, it is suggested to carry out research on measuring other aspects such as marketing and operational. 


\section{RE FERENCES}

Anthony, R.N., Hawkins, D.F., Merchant, K.A. (2011). Accounting: Text and Cases, 13th Ed. Asia: Mc.Graw - Hill International Edition.

Halkos G.E., Salamouris D.S., (2004), Efficiency measurement of the Greek commercial banks with the use of financial ratios: a data envelopment analysis approach, Management Accounting Research, 15, 201-224

Hempel, G., Simonson, D., and Coleman, A. (1994). Bank Management: Text and Cases, 4th Edition. John Wiley \& Sons, Inc.

Idris, M. (2016). Booming e-Commerce, Bisnis Pengiriman JNE Tumbuh diatas 30\% Setahun. Retrieved from http://www.detik.com

Katharina Lawi, GF. (2016). 60\% Pendapatan JNE dari eCommerce. Retrieved from http://www.bisnis.com

Kumbirai, M., Webb, R. (2010). A Financial Ratio Analysis of Commercial Bank Performance in South Africa. African Review of Economics and Finance, 2 (1), 30-53.

Mars Indonesia, PT. (2017). Studi E-Commerce Indonesia 2016. Retrieved from https://www.marsindonesia.com/products/business-reports/studi-e-commerce-indonesia-2016

Megaladevi, P. (2015). A study on financial performance analysis of the selected paper company with special reference to Tamil Nadu Newsprint and papers limited. International Journal of Recent Research Aspects, 2(4), 22-24.

Ministry of Foreign Affairs of Denmark. (2014). Indonesia E-commerce Country Fact Sheet.

Ministry of State Owned Enterprises. (2002). Keputusan Menteri Badan Usaha Milik Negara Nomor:KEP100/MBU/2002 Tentang Penilaian Tingkat Kesehatan Badan Usaha Milik Negara. Retrieved from http://jdih.bumn.go.id/baca/KEP-100/MBU/2002.pdf

Pos Indonesia, PT. (2010). Empowerment \& Modernization, 2009 Annual Report. Retrieved from http://www.posindonesia.co.id/wp-content/uploads/2016/01/Pos-Indonesia-Annual-Report2009.pdf

Pos Indonesia, PT. (2011). Empowerment \& Modernization, 2010 Annual Report. Retrieved from http://www.posindonesia.co.id/wp-content/uploads/2016/01/Pos-Indonesia-Annual-Report2010.pdf

Pos Indonesia, PT. (2012). Annual Report 2011. Retrieved from http://www.posindonesia.co.id/wpcontent/uploads/2016/01/Pos-Indonesia-Annual-Report-2011.pdf

Pos Indonesia, PT. (2013). Menuju Puncak Meraih Lebih, Aiming Higher Achieving More, 2012 Annual Report. Retrieved from http://www.posindonesia.co.id/wp-content/uploads/2016/10/Pos-IndonesiaAnnual-Report-2012.pdf

Pos Indonesia, PT. (2014). Terus Bergerak Meraih Masa Depan Yang Lebih Cerah, Move on to Brighter Future, 2013 Annual Report. Retrieved from http://www.posindonesia.co.id/wpcontent/uploads/2016/01/Pos-Indonesia-Annual-Report-2013.pdf

Pos Indonesia, PT. (2015). Membangun Kepercayaan \& Integritas, Building Integrity, and Trust, 2014 Annual Report. Retrieved from https://www.scribd.com/document/362915301/Pos-Indonesia-AnnualReport-2014-pdf

Pos Indonesia, PT. (2016). Revitalisasi Bisnis untuk Penciptaan Nilai, Business Revitalization for Creating Values, 2015 Annual Report. Retrieved from http://www.posindonesia.co.id/wpcontent/uploads/2016/10/Pos-Indonesia-Annual-Report-2015.pdf

Singapore Post Limited (2016). Indonesia: 9 eCommerce Facts. Retrieved from http://www.specommerce.com.s3.amazonaws.com/dl/fs/161102_fs_indonesia.pdf

Sinkey, J. (2002). Commercial Bank Financial Management: In the Financial-Services Industry, 6th Edition. NJ: Prentice Hall, Upper Saddle River.

Tarawneh, M. (2006). A comparison of financial performance in the banking sector: Some Evidence from Omani Commercial Banks. International Research Journal of Finance and Economics, 3, 101-112. 